LOCAL WISDOM, 10 (2): 63-74, 2018
Local Wisdom Scientific Online Journal
ISSN: 2086-3764

\title{
MORFOLOGI KAWASAN DAN TIPOLOGI RUMAH ADAT KAMPUNG MAHMUD KABUPATEN BANDUNG
}

\author{
Fenny Widiana \\ 176060500111002 \\ Fenny.widiana@gmail.com
}

\begin{abstract}
Abstrack
Keywords:

Indigenous village

Mahmud

Bandung, morpho-

logical area, building typology

Indonesia is an archipelago country that has diverse ethnic, cultural and customs. The diversity is reflected in the environment and traditional buildings of indigenous villages in each region. Currently, there are still some areas that still have and maintain the traditional village. One of them is the area of West Java. Kampung Mahmud is a periurban village in the city of Bandung. Kampung Mahmud has located in the village of Mekarrahayu Margaasih district of Bandung. Still retaining customs with respect to Karuhun (ancestors) is the hallmark of this village. The modernization and construction of the bridge by the government in 1997 has influenced changes in Mahmud village both macro on the region and micro on the building. This paper aims to find out the morphology of Kampung Adat Mahmud area and to know Typology of traditional house of Mahmud village. The method used in this paper is descriptive qualitative. The data collection method was conducted by literature study from journal and book about the theory of typology, morphology as well as about the traditional village of Mahmud. Data analysis method using diachronic and synchronous approach. The results obtained that the morphology of Mahmud customary village area in the form of orientation and the addition of building period. The orientation which initially centered on the mosque as a place of worship turned into centered toward the ancestral grave and then to the connecting road. While the typology of house building is influenced by climate factor, culture, environment, building technique, customary law, religion, and social relation of society.
\end{abstract}

Kata kunci:

kampung adat

Mahmud

Bandung,

Morfologi

kawasan, tipologi

bangunan

\begin{abstract}
Abstrak
Indonesia merupakan Negara kepulauan yang memiliki beragam suku bangsa, adat istiadat serta budaya. Keberagaman tersebut tercermin pada lingkungan dan bangunan tradisional pada kampung adat di masing-masing daerah. Saat ini masih terdapat beberapa daerah yang masih memiliki dan mempertahankan kampung adat. Salah satunya adalah daerah Jawa Barat. Kampung Mahmud adalah kampung peri-urban pada kota Bandung. Kampung Mahmud terletak di desa Mekarrahayu kecamatan Margaasih Kabupaten Bandung. Masih mempertahankan adat istiadat dengan menghormati Karuhun (nenek moyang) merupakan ciri khas dari kampung ini. Modernisasi dan pembangunan jembatan yang dilakukan pemerintah pada tahun 1997 telah mempengaruhi perubahan di kampung Mahmud baik secara makro pada kawasan maupun mikro pada bangunan. Tulisan ini bertujuan untuk mengetahui morfologi kawasan Kampung Adat Mahmud dan mengetahui Tipologi rumah Adat kampung Mahmud. Metode yang digunakan pada tulisan ini adalah deskriptif kualitatif. Metode pengumpulan data dilakukan dengan studi literature dari jurnal dan buku mengenai teori tipologi, morfologi serta mengenai kampung adat Mahmud. Metode analisa data menggunakan pendekatan diakronik dan sinkronik. Hasil yang didapat bahwa morfologi kawasan kampung adat Mahmud berupa peralihan orientasi dan penambahan masa bangunan. Orientasi yang awalnya berpusat pada masjid sebagai tempat ibadah, berubah menjadi berpusat ke arah makam leluhur dan kemudian ke jalan penghubung. Sedangkan tipologi bangunan rumah dipengaruhi oleh factor iklim, budaya, lingkungan, teknik mambangun, hukum adat, religi, dan hubungan sosial masyarakat.
\end{abstract}

@ 2017 The Authors. Published by GKAK UNMER Malang

*Corresponding Author: Fenny.widiana@gmail.com 


\section{Pendahuluan}

Indonesia merupakan Negara kepulauan yang memiliki beragam suku bangsa, adat istiadat serta budaya. Keberagaman tersebut tercermin pada lingkungan dan bangunan tradisional pada kampung adat di masing-masing daerah. Saat ini masih terdapat beberapa daerah yang masih memiliki dan mempertahankan kampung adat. Salah satunya adalah daerah Jawa Barat. Kampung adat di Jawa Barat yang masih bertahan di era modernisasi antara lain Kampung Naga, Kampung Gede Kasepuhan Ciptagelar, Kampung Pulo, Kampung Mahmud, Kampung Kuta dan lain-lain (Rif'ati dalam Kustianingrum, et al., 2013).

Kampung Mahmud adalah kampung peri-urban pada kota Bandung. Kampung Mahmud terletak di desa Mekarrahayu kecamatan Margaasih Kabupaten Bandung. Masih mempertahankan adat istiadat dengan menghormati Karuhun (nenek moyang) merupakan ciri khas dari kampung ini. Hal ini terlihat dari kehidupannya sehari-hari dengan melakukan ziarah, menghormati tetua, dan mematuhi berbagai batasan sakral atau pantangan.

Modernisasi, kemajuan teknologi dan komunikasi menuntut hadirnya arsitektur yang dapat memenuhi kebutuhan-kebutuhan baru tersebut. Hal ini memicu terjadinya perubahan-perubahan, dimulai dari mengganti material bangunan yang dirasakan sudah tidak sesuai dan sulit ditemukan. Demikian pula dengan bentuk dan gaya arsitektur bangunannya yang dirasakan sudah tidak dapat memenuhi kebutuhan saat ini. Hal seperti ini terjadi pula di Kampung Mahmud, sebuah kampung vernakular yang semula berada pada delta sungai Citarum di kabupaten Bandung.

Pemerintah Bandung membangun jembatan pada tahun 2007 untuk memudahkan akses menuju kampung Mahmud. Selain itu dibuat pula terminal angkutan umum yang menghubungkan kampung Mahmud dengan kampung-kampung sekitarnya. Hal ini memudahkan terjadinya komunikasi dan mendorong masuknya pendatang baru ke kampung Mahmud karena kepadatan di kampung sekitar. Hal ini berdampak terhadap percampuran budaya dan mengakibatkan mulai merosotnya nilai-nilai budaya asli Kampung Mahmud. Masyarakat sudah tidak menghiraukan pantangan-pantangan masa lalu. Perubahan alam dan lingkungan sekitar juga turut menjadi factor menyebab perubahan pemukiman kampung Mahmud. Secara fisik, perubahan tersebut terjadi pada kawasan kampung Mahmud secara makro dan secraa mikro pada bangunan-bangunan di kampung tersebut.

Dari permasalahan di atas, penulisan ini bertujuan untuk mengetahui morfologi kawasan Kampung Adat Mahmud dan mengetahui Tipologi rumah Adat kampung Mahmud.

\section{Metode}

Metode yang digunakan dalam penelitian ini adalah metode deskriptif kualitatif. Tujuan dari penelitian deskriptif adalah untuk "menggambarkan" dengan menggunakan kata-kata dan gambar untuk menjawab pertanyaan bagaimana tipologi dan morfologi bangunan rumah kampung adat Mahmud.

Tahapan penelitian meliputi pengumpuan data, analisa data dan penarikan kesimpulan. Metode pengumpulan data dilakukan dengan studi literature dari jurnal dan buku mengenai teori tipologi, morfologi serta mengenai kampung adat Mahmud. Penentuan sample dilakukan dengan metode purposive sampling dengan kriteria rumah yang masih asli dan sedikit mengalami perubahan (Septianto, 
et al., 2017 dan Krier, 2001). Variabel identifikasi yang digunakan secara mikro berupa sistem spasial (organisasi ruang dan pola hubungan ruang), fisik (atap, dinding, lanatai, material dan struktur konstruksi), dan model. Untuk identifikasi secara makro menggunakan variabel tata guna lahan dan pola plot (posisi/orientasi dan sirkulasi/jaringan jalan). Analisa data melalui pendekatan diakronik dan sinkronik untuk mengetahui penyebab perubahan kawasan (Aryati, 2012).

\section{Kajian Pustaka}

\section{Tipologi}

Tipologi dalam Kamus Besar Bahasa Indonesia, Wikipedia dan kamus Merriam-Webster berarti ilmu yang mempelajari atau mengklasifikasi berdasarkan type atau kategori kesamaan untuk memahami objek tertentu.

Tipologi menurut Ching (2007) adalah konsep memilah kelompok objek berdasarkan kesamaan sifat dasar seperti perletakan dan karakter visualnya, karena hampir semua bangunan terdapat unsur yang berulang dengan ukuran tertentu.

Tipologi sebagai studi untuk mempelajari objek-objek arsitektur dan mengelompokkannya berdasarkan kesamaan dalam hal tertentu yang dimiliki objek tersebut. Kesamaan atau keserupaan objek arsitektural dapat berupa kesamaan bentuk/sifat dasar, kesamaan fungsi, kesamaan asal-usul dan perkembangan serta latar belakang sosial ditempat objek tersebut berada, serta kesamaan gaya atau langgam (Muchamad, 2015).

Tipologi arsitektur adalah sebuah metode untuk mengklasifikasikan objek bangunan dengan kesamaan bahasa (komunikasi) yang berdasarkan atas karakter atau ciri sebuah bangunan. Ciri ini yang secara menyeluruh dapat digunakan sebagai patokan untuk dapat dikelompokkan seperti fungsi, ruang, bentuk, langgam, warna, skala, tekstur, garis, dan potongan-potongan bidang (Suharjanto, 2013).

Sulistijowati (Karisztia, Pangarsa, \& Antariksa, 2008) menjelaskan tipologi sebagai upaya untuk mengelompokkan berdasarkan aspek fungsi yang meliputi penggunaan ruang, struktural dan simbolis; aspek geometrik yang meliputi bentuk dan prinsip tatanan; dan aspek langgam yang meliputi periode, lokasi, politik, etnik dan budaya. Suatu kebudayaan dan lingkungan buatan dapat berubah secara bersamaan (Rapoport, A., and Altman, 1980). Perubahan lingkungan terbagi menjadi tiga bagian, yaitu core element yang mengalami perubahan lambat dan menjadi identitas pemilik arsitektur tersebut, peripheral element sebagai bagian yang tidak terlalu penting dan mudah berubah, new element sebagai bagian baru yang diadaptasi oleh pemilik arsitektur. Lingkungan yang berdasarkan budaya adalah lingkungan untuk kelompok dengan gaya hidup khusus yang membedakan dengan kelompok lain. Suatu lingkungan fisik permukiman menurut Harbaken (Lihawa, Suwarno, \& Nuryanti, 2006) dapat dililhat dari tiga aspek, yaitu sistem spasial (spasial system) yang berkaitan dengan ruang, organisasi ruang dan pola hubungan ruang; sistem fisik (physical system) yang berkaitan dengan konstruksi dan penggunaan material-material yang digunakan dalam mewujudkan suatu fisik bangunan; dan sistem model (stylistic system) yang berkaitan dengan langgam yang mewujudkan bentuk. Sistem fisik bangunan meliputi struktur, konstruksi atap, dinding dan lantai. Sistem model meliputi fasade, bentuk pintu dan jendela beserta unsur lainnya baik di dalam maupun di luar bangunan. 


\section{Morfologi}

Morfologi dalam Kamus Besar Bahasa Indonesia berarti ilmu pengetahuan yang mempelajari tentang bentuk luar dalam hubungannya dengan perkembangan. Morfologi dalam arsitektur merupakan studi mendasar dalam mengevaluasi tipe dan model yang memperlihatkan transformasi dan metamorfosa dengan kata lain morfologi merupakan studi tipologi dari transformasi (Mentayani, 2007). Menurut Carmona (2003) morfologi adalah kajian untuk menggali proses yang melatarbelakangi perubahan dan dinamika terbentunya lingkungan fisik yang terbentuk dari komponen tata guna lahan, struktur bangunan, pola plot, dan jaringan jalan.

\section{Sejarah Pembentukan / Perkembangan Kampung Adat Mahmud}

Kampung Mahmud adalah permukiman yang didirikan oleh Eyang Dalem Abdul Manaf, seorang misionaris Islam terkemuka dan merupakan keturunan ketujuh dari Srarif hidayatullah (Sunan Gunung Jati). Setelah tinggal di mekkah pada abad ke 15, beliau ingin pulang ke Indonesia tanpa bertemu dengan pejajah. Kemudian beliau berdoa dan pendapatkan petunjuk untuk mencari daerah rawa, didapatkan dekat sungai Citarum. Kemudian lahan tersebut ditimbun dan sungai dibelokkan sehingga kawasan sekitarnya menjadi tempat tinggal (Pernama dalam Pratiwi, 2017)

Kampung Mahmud berada pada batas kota dan desa di Bandung. Terletak di sebelah barat dari pusat administrasi desa Mekarrayahu dan dikelilingi sungai Citarum dengan luas sekitar 16 Ha. Secara administrasi kampung adat Mahmud memiliki batas sungai Citarum Lama pada sisi barat dan selatan, Desa Baladongan pada sisis timur dan sungai Citarum Baru di sebelah utara.

Berdasarkan Rencana Tata Ruang Wilayah Kabupaten Bandung tahun 2007 - 2027 dijelaskan bahwa Situs kampung Mahmud yang berada di kecamatan Margaasih termasuk ke dalam kawasan pariwisata Budaya yang harus dilindungi. Kampung Mahmud juga merupakan suatu permukiman adat, dimana ketentuan pemanfaatan ruang berdasarkan fungsi kawasan permukiman antara lain:

a. Dapat dibangun fasilitas yang dapat menunjang fungsi

b. Diperkenankan adanya bangunan yang menunjang fungsi kawasan/kegiatan utama untuk kepentingan umum, jalan yang sesuai kebutuhan, permukiman perdesaan dan pariwisata/agrowisata

c. Lahan terbangun dibatasi berdasarkan daya dukung dan daya tampung lingkungan berdasar kajian detil (permukiman kepadatan rendah)

Pengembangan kawasan perumahan, diarahkan untuk membatasi besaran KDB dan KLB pada setiap kavling rumah, membatasi proporsi kawasan perumahan maksimum $60 \%$ dari luas lahan yang sesuai. 


\section{Morfologi Kawasan dan Tipologi Rumah Adat Kampung Mahmud Kabupaten Bandung \\ Fenny Widiana}

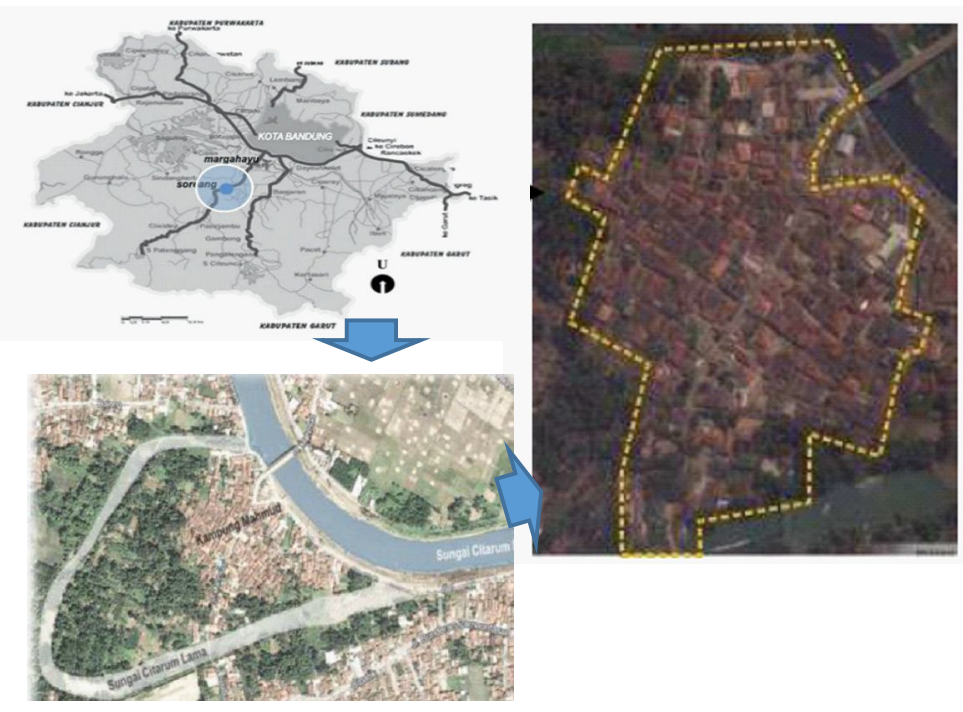

Gambar 1. Lokasi kampung Adat Mahmud

(Sumber: diolah dari Pratiwi \& Susanti I., 2017; Septianto, et al, 2014)

\section{Hasil Pembahasan}

\section{Tata guna lahan}

Penggunaan lahan pada kampung Adat Mahmud terdiri dari permukiman; lingkungan makam yang terbagi atas makam umum dan keluarga, makam Eyang Dalem Abdul manaf dan Eyang Agung Zainal Arifi, makam Eyang Agung Abdullah Gedung; masjid (lama dan baru); jalan serta ruang terbuka berupa kebun dan halaman.
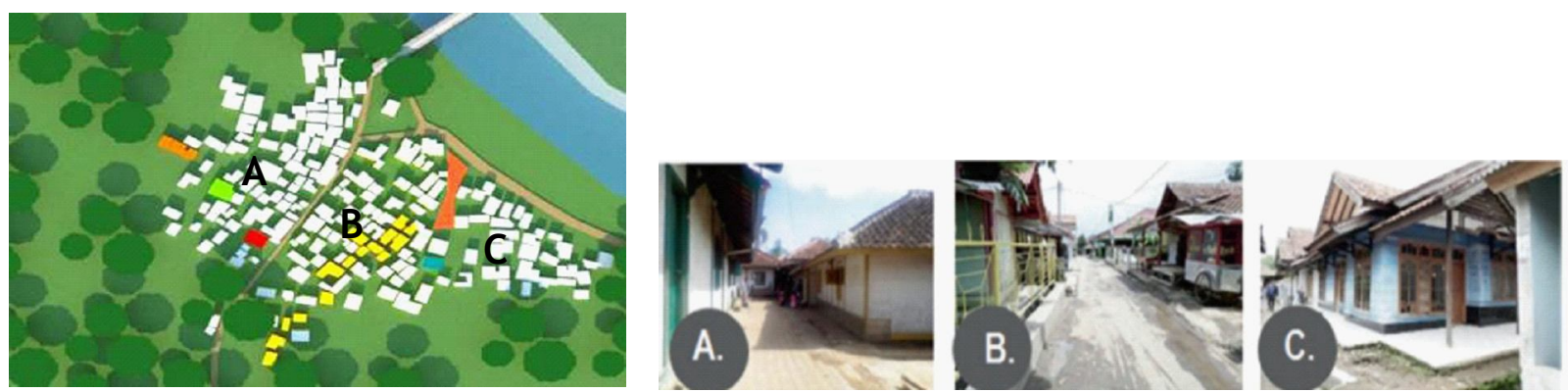

Keterangan :

Permukiman/rumah

Masjid lama

Masjid baru

Makam umum

Makam Mahmud

Penambahan bangunan

Gambar 2. Penggunaan lahan kampung Adat Mahmud (Sumber: ADRIANSYAH, et al, (2017) dan W.D. \& Susanti I. (2017)) 


\section{Pola plot}

Kondisi awal kampung Adat Mahmud berupa rawa dengan kadar air yang cukup tinggi sehingga bangunan yang sesuai adalah bangunan panggung. Kepercayaan masyarakat kampung Mahmud mempengaruhi orientasi bangunan. Pada masa awal pendirian kampung, orientasi massa bangunan menghadap masjid. Namun setelah Eyang Abdul manaf sebagai pendiri kampung meninggal dunia, orientasi massa bangunan berubah menghadap makam Eyang Abdul Manaf dan keluarganya. Hal ini merupakan suatu penghormatan warga kepada Eyang Abdul Manaf. Kondisi ekonomi masyarakat pada awal pembangunan kampung ditunjang dari hasil pertanian, masyarakat kampung Mahmud homogeny karena hampir semua berprofesi sebagai petani. Hal ini ditunjukan dengan posisi lahan pertanian yang mengelilingi bangunan rumah.

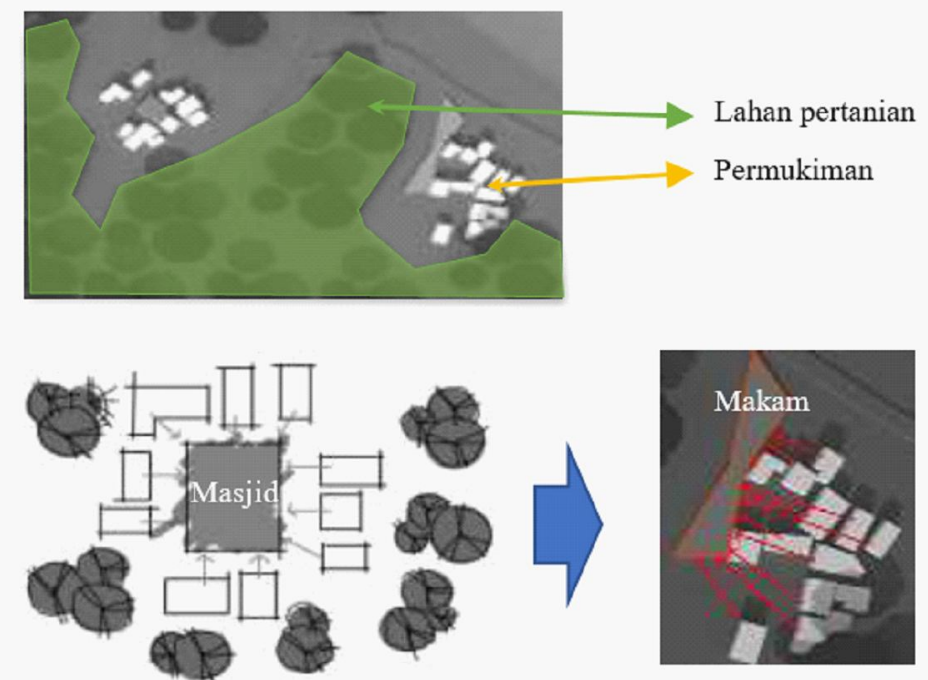

Gambar 3. Posisi lahan pertanian dan perubahan orientasi bangunan (Sumber: diolah dari ADRIANSYAH, et al, (2017))

Kampung Mahmud didirikan untuk tempat bersembunyi. Hal ini membentuk pola kampung yang terpusat dengan masjid sebagai titik pusatnya. Selain itu lokasi kawasan yang dikelilingi oleh aliran air sungai Citarum merupakan pagar pertahanan alami yang melindungi kawasan dari serangan penjajah. perkembangan kampung Mahmud dibagi menjadi empat periode yakni periode sebelum kemerdekaan, sesudah kemerdekaan, tahun 2000-an, dan masa tahun 2014. Keadaan kampung Mahmud pada periode sebelum kemerdekaan masih berpusat pada satu titik, yakni masjid pertama Al Jami'. Akses menuju kampung hanya dapat dicapai dengan menggunakan rakit. Keadaan kampung Mahmud setelah masa kemerdekaan, telah dibuat akses jalan masuk sberupa dua jembatan yang menghubungkan kampung Adat Mahmud (yang berada di delta sungai Citarum) ke daratan. Hal ini membuat kampung Adat Mahmud lebih mudah dicapai. Meskipun demikian tatanan massa bangunan nya masih berorientasi pada masjid dan makam leluhur sesuai dengan adat budaya masyarakat penguhuni. 

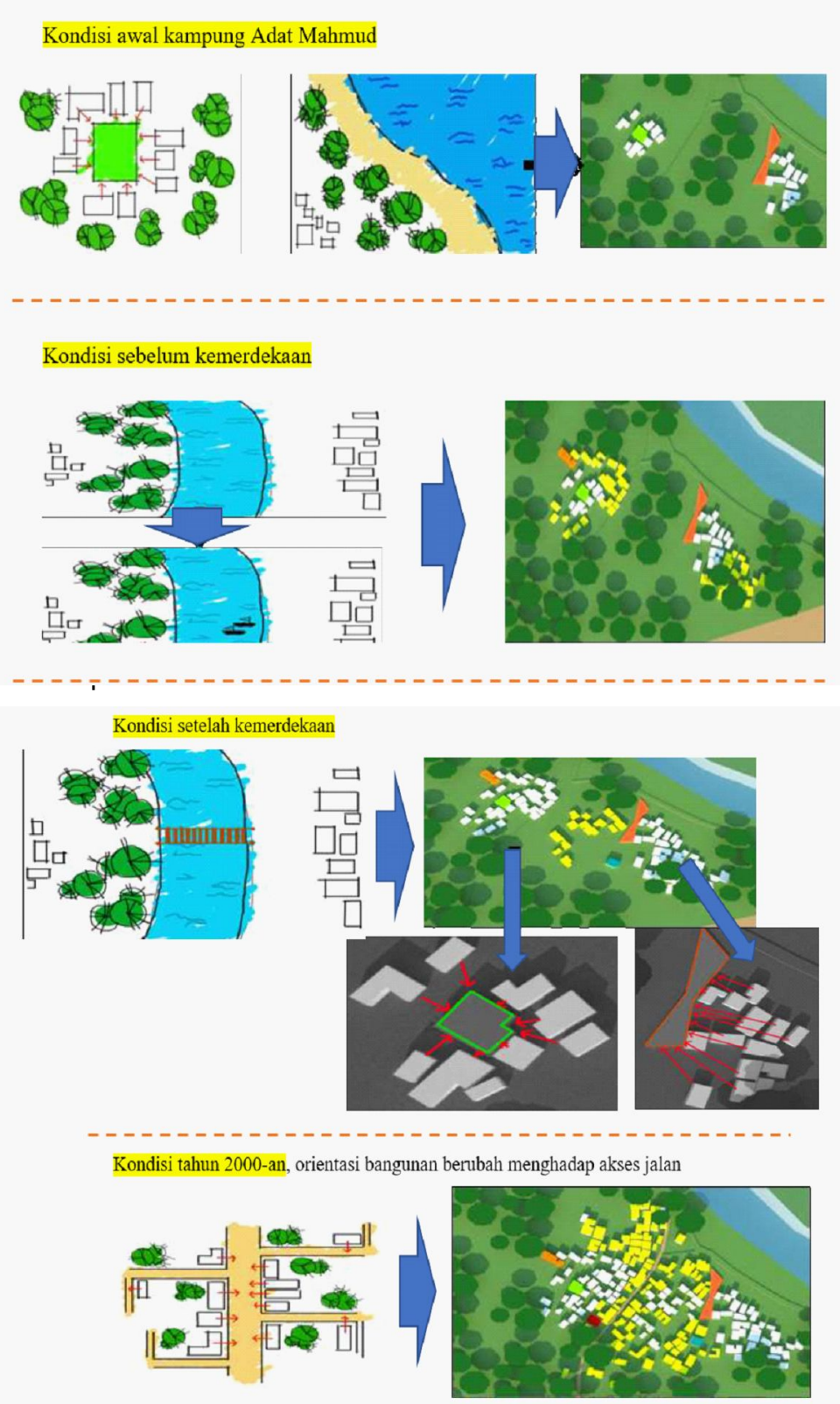

Kondisi tahun 2014

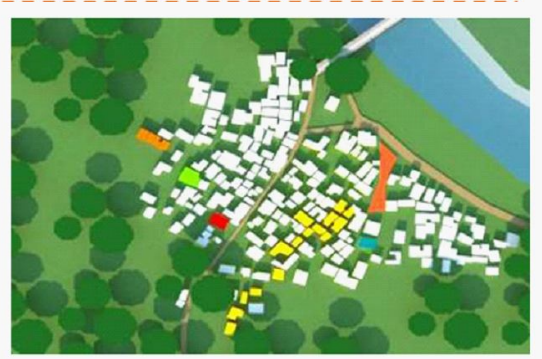

Gambar 4. Morfologi Kawasan kampung adat Mahmud (Sumber: diolah dari ADRIANSYAH, et al, (2017)) 
Pada tahun 2000-an, Kondisi kampung Mahmud mengalami perubahan yang sangat nyata. Kemudahan akses memicu terjadinya perubahan. Dengan dibuatnya jembatan menjadikan warga dari kampung sekitar pindah ke kampung Mahmud. Perpindahan ini ditandai dengan berkembangnya home industry berupa pembuatan meubel. Usaha ini bukan merupakan mata pencaharian warga kampung Mahmud. Selain itu bertambahnya jumlah warga kampung Mahmud sejalan dengan bertambahnya jumlah massa bangunan. Perkembangan ini ditindak lanjuti oleh Pemerintah Daerah dengan membagi kampung menjadi 2 Rukun Tetangga (RT). Dampak yang ditimbulkan pada dibukanya akses menuju kampung Mahmud dari barat dan utara memicu terbentuknya jalur-jalur transportasi lain. Kondisi ini merubah orientasi massa bangunan baru, tidak lagi pada Mesjid dan Makam leluhur tetapi berorientasi menghadap jalan. Hal menjadi sesuatu yang wajar terutama bagi mereka yang membuka usaha (meubel, toko/warung) untuk akses yang lebih mudah dijangkau.

Kondisi saat ini, sepintas kampung Mahmud terlihat seperti layaknya kampung penduduk. Kampung ini banyak dikunjungi masyarakat karena daya Tarik sejarahnya. Daya Tarik tersebut berupa wisata religi dengan makam leluhur Eyang Abdul Manaf dan kampung vernacular yang baru dapat dilihat apabila telah masuk ke dalam kawasan. Beberapa rumah vernacular sudah tidak utuh lagi bertransformasi mengikuti tuntunan dan kebutuhan saat ini.

\section{Konsep bangunan rumah adat kampung Mahmud}

Sampel untuk menganalisa tipologi rumah adat kampung Makmud ini diambil berdasarkan kriteria keaslian bangunan dan sedikit perubahan, sehingga didapatkan sampel yang berada pada plot permukiman berlabel "A" pada gambar di bawah ini yang berada di area dekat makam leluhur Eyang Abdul Manaf.

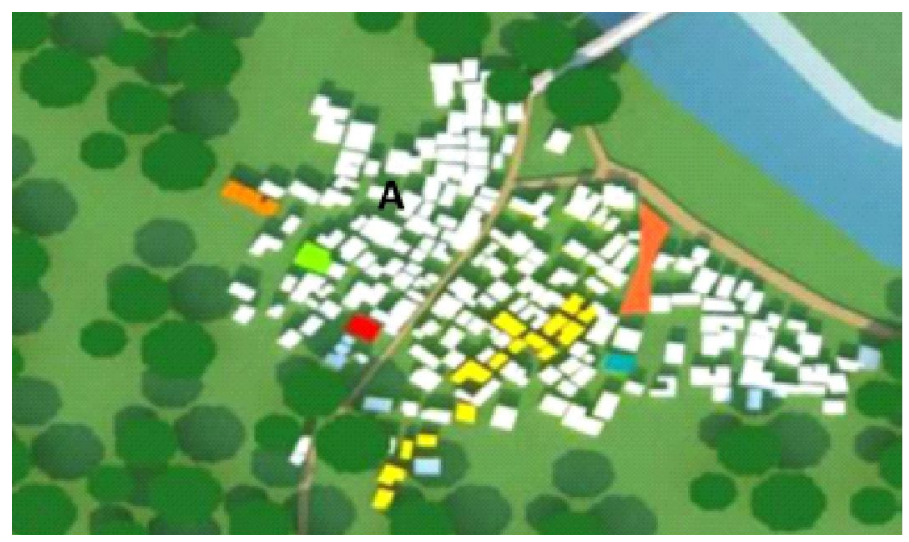

Gambar 5. Letak sampel rumah adat kampung Mahmud (Sumber: diolah dari ADRIANSYAH, et al, (2017) 
Dari data yang didapat, terdapat tiga jenis rumah yang berbeda, yaitu:

a. Bentuk tipologi bangunan 1

Susunan spasial pada tipe bangunan 1 berbentuk L dan terdiri dari ruang: tengah imah, kamar tidur, goah dan dapur.
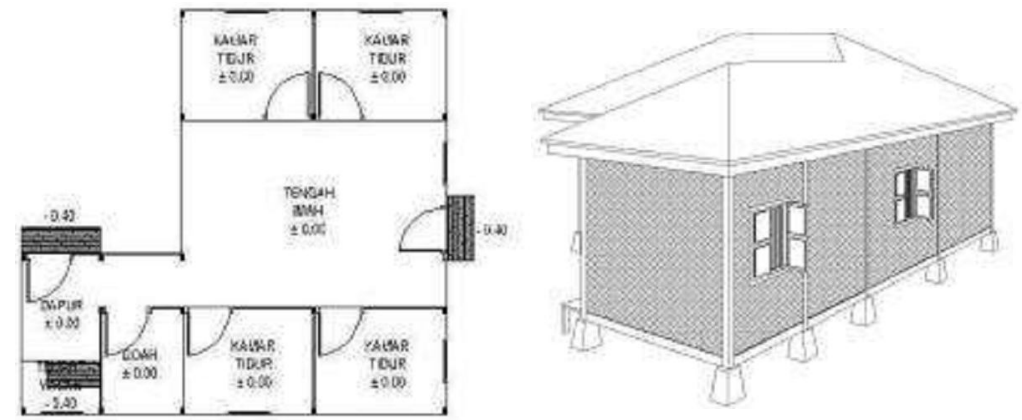

Gambar 6. Denah dan perspektif tipe bangunan 1

Pada aspek fisik terbagi menjadi:

- Atap : menggunakan struktur rangka kayu dengan bentuk perisai

- Dinding : bilik bambu

- Lantai : menggunakan sistem struktur panggung

- Pintu dan jendela : menggunakan papan kayu, tidak berkaca

b. Bentuk tipologi bangunan 2

Susunan spasial pada tipe bangunan 2 berbentuk L dan terdiri dari ruang: tepas, tengah imah, kamar tidur, goah dan dapur.
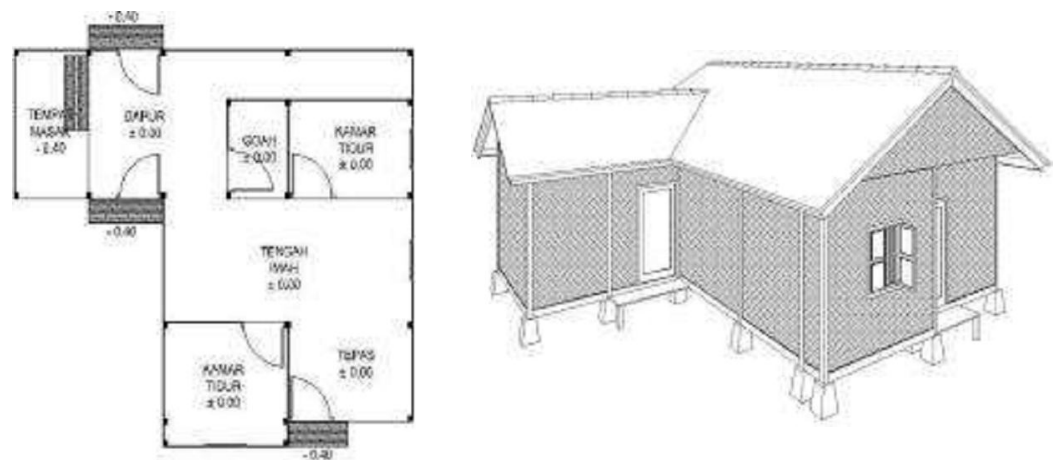

Gambar 7. Denah dan perspektif tipe bangunan 2 
Pada aspek fisik terbagi menjadi:

- Atap

: menggunakan struktur rangka kayu dengan bentuk perisai

- Dinding

: bilik bambu

- Lantai

: menggunakan sistem struktur panggung

- Pintu dan jendela : menggunakan papan kayu, tidak berkaca

c. Bentuk tipologi bangunan 3

Susunan spasial pada tipe bangunan 3 berbentuk persegi dan terdiri dari ruang: tepas, tengah imah, kamar tidur, goah dan dapur.

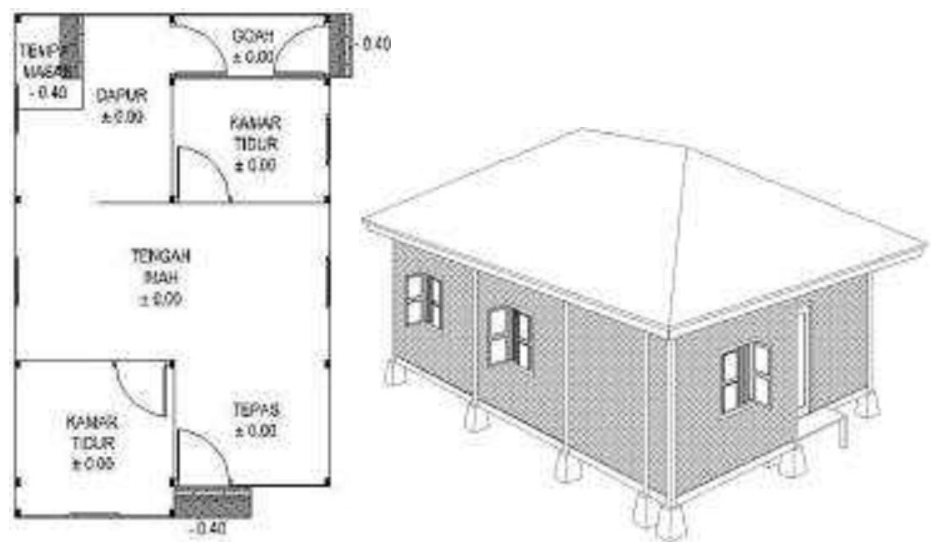

Gambar 8. Denah dan perspektif tipe bangunan 3

Pada aspek fisik terbagi menjadi:

- Atap

- Dinding

- Lantai

- Pintu dan jendela : menggunakan papan kayu, tidak berkaca.

Secara garis besar ciri khas bangunan rumah di Kampung Mahmud adalah rumah panggung berbentuk L, walaupun ada pula yang berbentuk persegi panjang. Ukuran bangunannya relatif besar, dan dihuni keluarga besar. Rumah asli di Kampung Mahmud, mempunyai ruang depan (tepas), tengah rumah (tengah imah), kamar, dapur, dan goah. Pola spasial pada bangunan rumah dipengaruhi oleh hubungan sosial, lingkungan alam serta hukum adat yang dianut masyarakat Kampung Mahmud (Septianto, et al., 2017). Hubungan sosial masyarakat Kampung Mahmud sangatlah kental dengan kepercayaan agamanya, khususnya agama Islam. Besaran ruang tengah (tengah imah) memiliki besaran yang cukup menampung orang banyak, ruang tersebut biasanya di gunakan untuk kegiatan keagaman yang rutin oleh masyarakat Kampung Mahmud. Sedangkan hukum adat yang berlaku tidak memperbolehkan membangun unsur yang kotor seperti toilet dan tidak boleh membuat sumur, karena 


\section{Morfologi Kawasan dan Tipologi Rumah Adat Kampung Mahmud Kabupaten Bandung}

Fenny Widiana

tidak memungkinkan membuat sumur di tanah yang masih labil yang akan mengakibatkan longsor. Masyarakat Kampung Mahmud memanfaatkan sungai citarum menjadi sumber air bersih untuk keperluan hidup.

Bentuk fisik bangunan rumah di kampung Mahmud umumnya berupa rumah panggung. Struktur panggung tersebut menggunakan material kayu sebagai struktur utama dan struktur atap, sedangkan material bambu sebagai dinding bilik dan lantai palupuh. Atap bangunannya berbentuk perisai dengan penutup atap dari genting. Bentuk fisik bangunan rumah dipengaruhi oleh iklim dan lingkungan sekitar; budaya; teknik membangun serta hukum adat (Septianto, et al., 2017). Iklim dan lingkungan sekitar mempengaruhi bentuk atap yang miring serta penggunaan material alam yang tersedia di sekitarnya, yaitu kayu dan bambu. Lingkungan alam juga mempengaruhi bentuk rumah panggung. Pada keadaan tanah labil hasil penimbunan rawa hanya struktur panggung yang dapat digunakan. Unsur budaya dan teknik membangun yang dikerjakan oleh masyarakat sendiri mengakibatkan bangunan rumah bertipe sama dan menggunakan material yang sama. Hal ini diperkuat dengan hukum adat yang mengharuskan rumah berpanggung atau berkolong dan memakain bahan material yang ramah lingkungan.

\section{Kesimpulan}

Morfologi kawasan kampung adat Mahmud berupa peralihan orientasi dan penambahan masa bangunan. Orientasi yang awalnya berpusat pada masjid sebagai tempat ibadah, berubah menjadi berpusat ke arah makam leluhur ketika pendiri kampung adat tersebut wafat. Hal ini sebagai bentuk pengormatan masyarakat terhadap pendiri kampung adat Mahmud. Setelah pemerintah membangun jembatan sebagai akses baru, orientasi bangunan berubah mengarah ke jalan penghubung, hal ini lebih dikarernakan aspek ekonomi.

Tipologi bangunan rumah adat kampung Mahmud hanya memiliki ruang tepas, tengah imah, kamar, goah dan dapur. Sedangkan struktur dan materialnya masih menggunakan bahan alami. Beberapa factor yang mempengaruhi tipologi berserta perubahannya adalah factor iklim, budaya, lingkungan, teknik mambangun, hokum adat, religi, dan hubungan sosial masyarakat.

\section{Daftar Pustaka}

ADRIANSYAH, P., LESTARI, N. Y., HERDI, E., AKBARA, \& SOEWARNO, N. (2014). KAJIAN PERKEMBANGAN TATANAN MASSA BANGUNAN PADA KAMPUNG VERNAKULAR “KAMPUNG MAHMUD.” Jurnal Reka Karsa Arsitektur Itenas, 2(4).

Aryati, Allafa., Antariksa., Wardani, DK. (2012). Perubahan Kawasan Kampung Arab Kota Malang. Arsitektur ejournal, 5 (1). 47-59.

Ching, F. D. K. (2007). Architecture Form, Space, and Order (Third edit). New Jersey: John Wiley \& Sons, Inc.

Karisztia, A. D., Pangarsa, G. W., \& Antariksa. (2008). TIPOLOGI FAÇADE RUMAH TINGGAL KOLONIAL BELANDA DI KAYUTANGAN - MALANG. arsitektur e-Journal, 1(2).

Krier, R. 2001. Komposisi Arsitektur. Jakarta: Erlangga.

Kustianingrum, D., Sonjaya, O., \& Ginanjar, Y. (2013). KAJIAN POLA PENATAAN MASSA DAN TIPOLOGI BENTUK BANGUNAN KAMPUNG ADAT DUKUH di GARUT, JAWA BARAT. Jurnal Online Institut Teknologi Nasional, 1(3), 1-13. 
Lihawa, H. R., Suwarno, N., \& Nuryanti, W. (2006). TIPOLOGI ARSITEKTUR RUMAH TINGG AL Studi Kasus Masyarakat Jawa Tondano (Jaton) Di Desa Reksonegoro Kabupaten Gorontalo. Universitas Gadjah Mada.

Mentayani, I., Dila, M. T., \& Andini, N. (2007). Tipologi dan Morfologi Arsitektur Suku Banjar di Kal-Sel. INFO TEKNIK, 8(2), 114-122.

Muchamad, B. N. (2015). ANALISIS TIPOMORFOLOGI SEBAGAI PENDEKATAN PERENCANAAN TERHADAP ANCAMAN BENCANA DI KOTA BANJARMASIN. In Seminar Nasional Mitigasi dan Ketahanan terhadap Bencana (hal. 1-8). Semarang.

Rapoport, A., and Altman, I. (1980). Human Behavior and Environment. New York: Plenum Press.

Rencana Tata Ruang Wilayah Kabupaten Bandung tahun 2007 - 2027.

Suharjanto, G. (2013). KETERKAITAN TIPOLOGI DENGAN FUNGSI DAN BENTUK: STUDI KASUS BANGUNAN MASJID. ComTech, 4(9), 975-982.

Pratiwi, W.D., \& Susanti I., S. (2017). The Impact of Religious Tourism on a Village of Peri-urban Bandung: Transformation in Placemaking. In 6th International Conference of Arte-Polis (hal. 61-72). Singapore: Springers. https:// doi.org/https://doi.org/10.1007/978-981-10-5481-5_7

Septianto, E., Hakim, A. R., Sudrajat, R. septian, Nurzaman, S., \& Suparman, Y. (2014). KAJIAN ARSITEKTUR VERNAKULAR PADA BANGUNAN DI KAMPUNG MAHMUD. Jurnal Reka Karsa Arsitektur Itenas, 2(4), 110. 